\title{
視覚探索による目標物の発見についで
}

\section{伊藤 郁男**}

\begin{abstract}
Search experiments by visual sense were executed, and the rate of finding an object, $\mathrm{P}$ was introduced as an equation of $P=1-e^{-r t}$, where $r$ is the difficulty of finding.
\end{abstract}

Some formulas with respect to $r$ were gotten. Proceeding the experiments in both methods of parallel and random search in finding the same specific object at the same condition, the merits and demerits with these two methods were compared and discussed.

It was concluded that the random search was advantageous in such simple condition as a small number of objects, while the parallal search exceled on the contrary in the complicated condition.

Mean finding times differed much on each other depending on the way of arrangement of objects. Two ways were done, one of which was that the objects were distributed in and mixed homogeneously with the back ground, and the other was that the all objects were concentrated together themselves as a cluster. Quantitative relationships between these two ways were obtained by experiments.

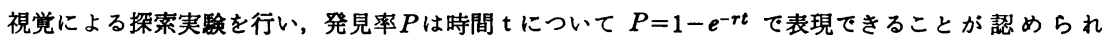
た. そして発見の難易は上式中の $\gamma$ の值によって整理でき，多くの実験式をえた.

さらに同一環境，同一目標の発見に関して，平行探索とランダム探索の両法について実験し，それぞ れの平均発見時間を測定した. 両方法の優劣は探索対象群（虚目標も含めて）の個数によって異なり， 対象物の少ない簡単な探索ではランダム探索が, 被雑な対象の場合には平行探索がそれぞれ有利であっ た.

また目標の発見の速さは，対象群を環境中に点在させるか，1個所に集中させるかによっても異なり， 対象の個数が少ない場合には後者がはるかに有利であることが示峻された。

\section{1. ま えがき}

いわゆるものを探すことは，日常多く経験するところ である.ここでは眼前にあるものを視覚によって探索す る場合について考える.

視覚表示に関しては, コーディングや計器表示と関連

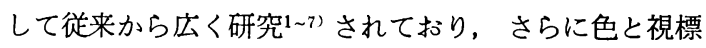
発見の研究についても, 筆者の知る範囲では, 色コー ドと他のコードとの比較研究として $\mathrm{Hitt}^{8)}$ の研究や, Smith と Thomas ${ }^{9)}$ の研究が，また色と発見に関連し て Smith ${ }^{10)}$ の研究が注目される.このほか最近では,

* 昭和 53 年 3 月 9 日受付

** 関西大学 Kansai Univ.
「色と視認性の定量化」と題する谷島ら ${ }^{11}$ の研究，また 「色彩情報と位置認知」に関して石橋ら ${ }^{12)}$ の報告がみら れる.

さて前報13)では，前方の 1 点を凝視した場合の発見確 率を視野との関係において報告したが, 本報ではこれに 続いて眼球も頭部む自由に回転することを許して，むし ろ積極的に目標物の発見に努める場合を取り扱う.これ は例えば, 地図や時間表から特定の目標を探し出す場合 とか, 雑多に混在する対象群から特定の目標物を探し当 てる場合とかを想定している.ここで問題をさらに簡単 にするため，それ自身に意味をもつものや，言語上の対 象は除外し, 問題を単純な色彩や記号の識別に限 定す る.

前報 ${ }^{13)} て ゙$ 述べたごとく，発見と視覚は別物である が, 両者はしかし根底に执いて深く関連している. 本報 
ではこれらの事柄について，後述する 2 とおりの方法に よって実験した。

\section{2. 実 験 法}

\section{2-1 視標実験}

実験装置は前報 ${ }^{13)}$ のものとほとんど同一であるが，実 験平板 (以下簡単に板) を大形 $(1,800 \mathrm{~mm} \times 1,800 \mathrm{~mm}$ ) とし, 直径 $10 \mathrm{~mm}$ の円れを中心から放射状に, 中心間距 離 $30 \mathrm{~mm}$ の間隔で 1 列に 20 23 個の割合であけ，これら の列が 32 本ある. これら総数 656 個のれに板の背後か ら視標棒を静かに㨂入し，板から $750 \mathrm{~mm}$ 離れた被験者 に発見させる. 挿入されるれの順序は，あらかじめ用意 されたれの番地とランダム表とにより全く独立に選定さ れ，しかも 1 回の実験で必ず 1 回だけ平等に割り当てら れる. 板は実験により, 全面白色の場合と, 第 $1 \sim 4$ 象限 の順に白, 赤, 黒, 緑の各色に塗り分けられた場合とが ある. これらの色は, 色度測定の実測值は表 2 で後述す るが，市販のマンセルカラーブック (JIS Z 8721-1964) と比較すればそれぞれ色相, 彩度, 明度の順に, 赤 ( 5 $R, 15,4)$ ，緑 $(10 G, 4,3.5)$ および白（明度9.5), 黒（明度 1.5）である.

視標が被験者の眼に対して張る視角は, 板の中心部で 約 $46^{\prime}$ であるが，板の外端では約 $24^{\prime}$ となっている.

被験者は男子学生 20 名て, 試行数は 1 つの実験につ き 600 回である.

かくて照度一定(約 500 lux)の下で, 毎回の発見に要す る時間 $t$ を測定し， $t$ 秒をでに発見した回数 $x$ を試行数 $N$ で割ると, $P=x / N$ が時刻 $t$ までの累積発見確率であ る. その実測例を図 1 に示す。これらのデータから $\log _{10}$ $(1-P)$ を作り $t$ についてプロットすれば図 2 をうる.こ の結果，つぎの実験式をうる.すなわち

$$
P=1-e^{-r t}
$$

ここに $r$ は視標の発見の難易を表す数值で, 瞬間発見確 率密度と呼ばれるものである.

\section{2-2 カード実験}

図 3 に示すごときカードを縱横それぞれ 20 枚ずつ, 合計 400 枚，吵間なくボード上に配列する．各カードは 黄, 赤, 青, 緑および茶の 5 色のいずれかに着色され, これらの色のマンセル色度は, 色相, 彩度, 明度の順に 黄 $(5 Y, 12,8.5)$, 赤 $(5 R, 15,4.5)$, 青 ( $5 P B$, $9,4.5)$, 緑 $(7.5 G, 4 ， 4)$ および茶 $(10 R, 5,3.5)$ である. そしてこれらのカードには，さらに中央部に 1 杵のアラビア数字が一字印刷されている (Color and

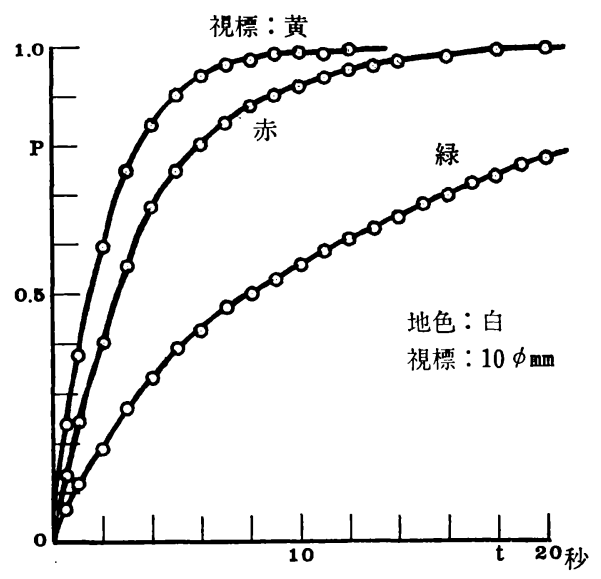

図 1 白地における各色視標の発見確率

Fig. 1 Finding rate of visual objects of each hue on the white base plate.

numerical Coding, 活字の太さは字の高さの約 $1 / 5$ の もの）ものと，印字のないダミーカードの 2 種類があ る.

被験者は昼光下で, $300 \mathrm{~mm}$ 離れた位置から指定された 目標カード（色と数字を指定，たとえば黄色の 0 ）を合 図と同時に探索を開始する，一枚のカードが被験者の眼 に対して張る視角は，ボードの中央部で $8.5^{\circ}$ であり，ま たカード中の数字が張る視角は $57^{\prime}$ である.カードがボ 一ドの端で読まれるときは, これらの值はそれぞれ $2.5^{\circ}$, $17^{\prime}$ となる.

探索には，カードを最上段から横書きの書物を読む要 領で順次読み下す, いわゆる平行探索 (parallel search) と，自由気侐に眼を走らせるランダ ム探索（random search) と，これらを適当に配合した混合探索とが考え られるが，今回は前 2 者の方法によって実験した. 被験 者は男子学生 20 名で, 試行数は各組の実験に 対し 100 回である。

\section{3. 実 験 結 果}

\section{3-1 視標実験}

平板の地色(以下簡単に地色)を全面, 白 $(x=0.316$, $y=0.323, Y=87.86)$ とし, 視標の色は表 1 に示すご とく 6 とおりに変え，図 2 の経路を経て $r$ を求めると表 1 の下段に示すごとくになる. これを視標の明度 $(Y)$ によって整理すれば図 4 をうる.ここで 6 色の視標のマ ンセル色度表示は, 色相, 彩度, 明度の順に, それぞ れ, 黄 $(2.5 Y, 12,8)$, も共 $(10 G Y, 10$ 以上, 7 以 上), 青 $(2.5 P B, 8,4)$, 赤 $(5 R, 15,4)$, 緑 $(10 G$, 

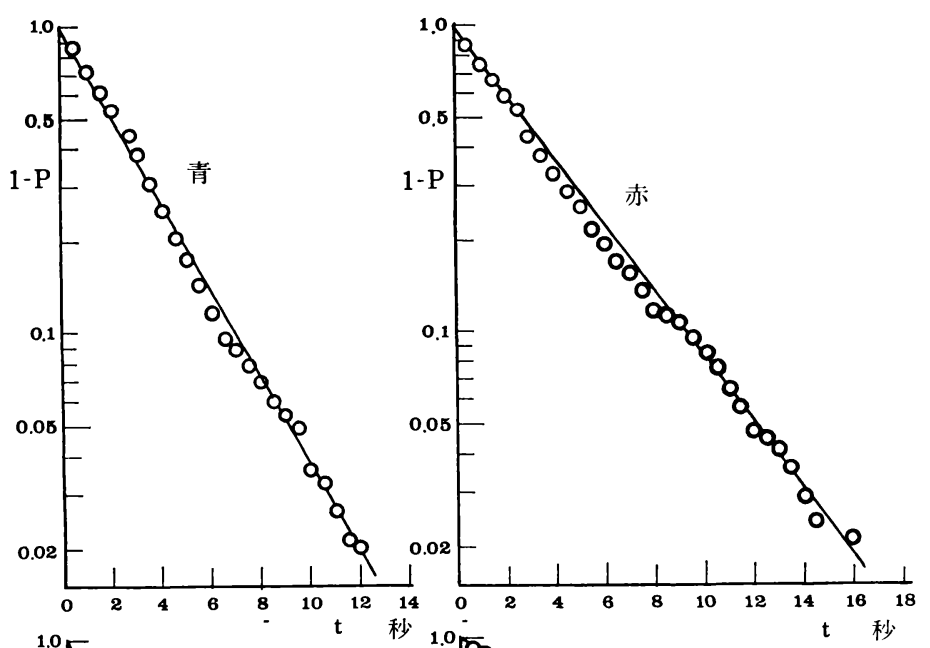

図 $2 \log _{10}(1-P)$ 対 $\mathrm{t}$ （地色：白, 視標 $10 \phi$ の各色）

Fig. $2 \log _{10}(1-P)$ to $t$. (Color of base is white and diameter of objects are 10 in millimeter)
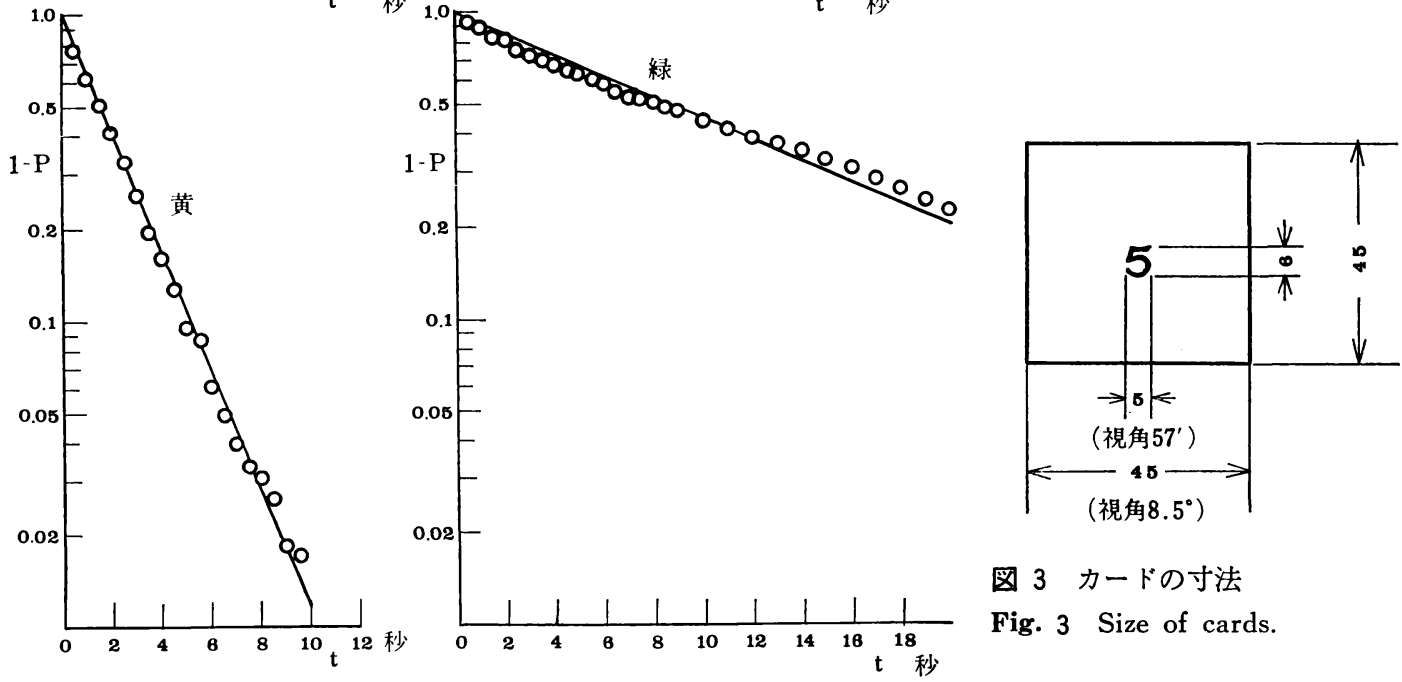

図 3 カードの寸法

Fig. 3 Size of cards.

表 1 視標の色と $r$ の值（地色が白のとき）

Tab. 1 Color of objects and their $\gamma$. (Color of base is white)

\begin{tabular}{c|c|c|c|c|c|c|c}
\hline \multicolumn{2}{c|}{ 視標の色 } & 白 & 黄 & もえ黄 & 青 & 赤 & 緑 \\
\hline \multirow{2}{*}{$\begin{array}{l}\text { 視 } \\
\text { 標 }\end{array}$} & $x$ & 0.316 & 0.444 & 0.286 & 0.245 & 0.452 & 0.292 \\
\hline$y$ & 0.323 & 0.441 & 0.285 & 0.248 & 0.331 & 0.324 \\
\hline & $Y$ & 87.86 & 62.47 & 40.71 & 20.74 & 17.57 & 14.80 \\
\hline & $r$ & 0.452 & 0.433 & 0.332 & 0.332 & 0.259 & 0.067 \\
\hline
\end{tabular}

\section{4，3.5）および白（明度 9.5）である.}

地色を白以外に塗るとき実験の能率を向上する目的

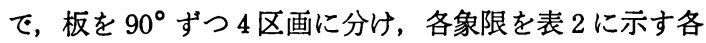
色（マンセル色度は既述のとおり）に塗り分けて実験し た. そしてデータを各地色別に整理した上ての白地のデ ータと，板の全面を白で 1 色にしたときの前記データを
比較して全く変化のないことが確認できたのでこの簡 便法の精度は信頼しうる.

かくて視標に赤を用い，地色を種々に変えたときの $\gamma$ の值を表 2 の下段に示す. この よって整理したものが図 5 である.図 $4 ， 5$ によれば, 明度 $(Y)$ の值がともに 20 以下のところで $r$ の值が急激 
図 4 視標の違いと $r$

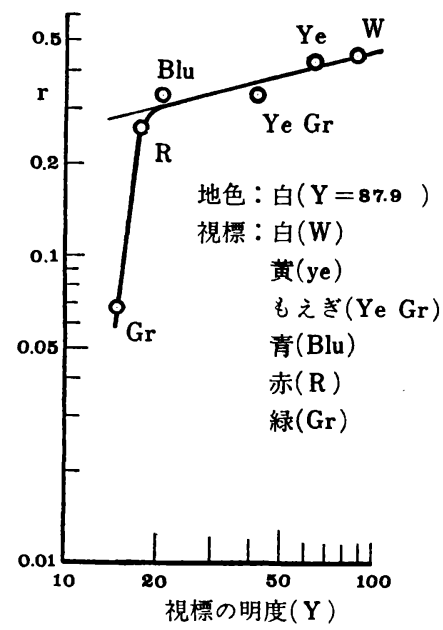

Fig. $4 r$ with respect to the color lightness of visual objects.

に減（増）じている．そして図 4 から，地色が明るい白 地のときでもやはり明るい視標の方が, 暗い視標より発 見されやすい様子がわかる. しかしこれは，白地に白図 は発見され難いだろろとする常識に反している.これに ついて筆者はつぎのように解訳している. すなわち，板 に貫通してあけられた円れ（視標の挿入れ）は正面から は黒く見えるので，地が白の場合は，それとの対照が鋭 い. そこに白の視標が掩入されれば, 無挿入のれ群と掩 入孔との対比が明確となる.このとき視標が白以外の暗 い色であったとすれば，この対比は小さくなり発見率は 低下するであろう．すなわちこの実験は，白地に白図の 発見とみるよりは白地中に黒の小円群で画かれた幾何図 形の一部の微小変更に対する被験者の反応とみた方が理 解されやすい。

さて次に図 5 によると視標が暗い赤色のときでも，地 色がさらに暗い色の方が発見されやすいことを示してい る. この事実も上記のごとく無挿入れとの対比で解訳す

表 2 各地色と $r$ の值 (視標は赤)

Tab. 2 Color of bases and $\gamma$. (visual objects are red)

\begin{tabular}{c|c|c|c|c|c}
\hline \multicolumn{2}{c|}{ 地の色 } & 白 & 赤 & 緑 & 黒 \\
\hline $\begin{array}{c}\text { 地 } \\
\text { 色 } \\
\text { の }\end{array}$ & $y$ & 0.316 & 0.452 & 0.292 & 0.323 \\
\hline & $Y$ & 87.86 & 17.57 & 14.80 & 11.85 \\
\hline \multicolumn{1}{r|r}{$r$} & 0.248 & 0.276 & 0.519 & 0.461 \\
\hline
\end{tabular}

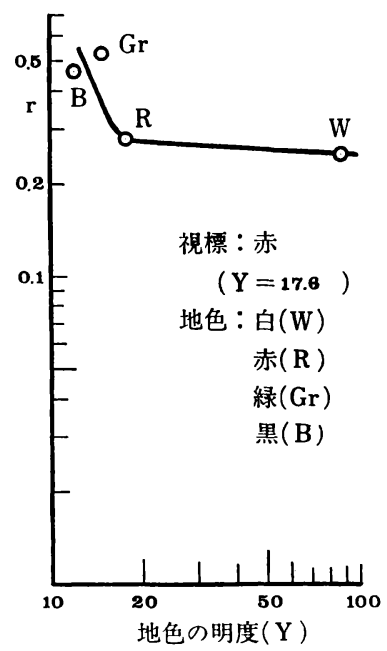

図 5 地色の違いと $\gamma$

Fig. $5 r$ with respect to the color lightness of base.

れば理解できる.

図 4 から, $20<Y<100$ の範囲で

$$
r=0.145 Y^{0.25}
$$

なる実験式をうる.

\section{3-2 カード実験}

実験に用いた各カードは表 3 に示した 5 色のどれかに 着色され，これらがランダムに混合してボード上に配列 されている.いまこれら 5 色中の 1 色（たとえば黄色） を目標色に選へば, 他の 4 色は環境色となる. 目標色力 一ド中の特定の数字（たとえば0）のカードを目標カー ドとすれば， 0 以外の黄色 $\left(y_{e}\right)$ カードは，まぎらわし いカード（すなわち虚目標カード）となる．目標カード （この例では $\left.y_{e}-0\right)$ は 1 枚だけであり，目標色カード の枚数 $n$ を変化させたときの発見の速さを, 平行探索と ランダム探索（以下簡単にそれぞれ $P$ 探索打よび $R$ 探 索)によって求める.この際板上のカードは目標色の $n$ 枚を除いた $(400-n)$ 枚を残りの 4 色で等分に分け，目標 色の $n$ 枚と合わせてょく混ぜた上で板上に配列される.

いま $R$ 探索において発見までに要した時間を $t$ とし， $t$ 秒以内に発見できた回数を全試行数で割った值を $P$ と し， $\log _{10}(1-P)$ を $t$ についてプットすれは，図 2 と 全く同様に図 6 をうる。これから $\gamma$ を算定し $n$ について 整理すれば図 7 がえられる. nが增すほど発見し難くな るのは当然であるが，定量的には次の実験式がえられ る.すなわち, 目標色が黄色の場合の $R$ 探索では,

$$
r=2.07 n^{-0.58}
$$


表 3 カードの色

Tab. 3 Color of cards.

\begin{tabular}{c|c|c|c|c|c|c}
\hline \multicolumn{2}{c|}{$\begin{array}{c}\text { カード } \\
\text { の }\end{array}$} & 黄 & 赤 & 青 & 緑 & 茶 \\
\hline $\begin{array}{c}\text { カ } \\
\text { ト }\end{array}$ & $x$ & 0.436 & 0.447 & 0.251 & 0.286 & 0.346 \\
\hline \begin{tabular}{c} 
の \\
\hline
\end{tabular} & 0.432 & 0.312 & 0.251 & 0.318 & 0.329 \\
\hline$Y$ & 66.05 & 21.57 & 21.41 & 18.99 & 18.66 \\
\hline
\end{tabular}

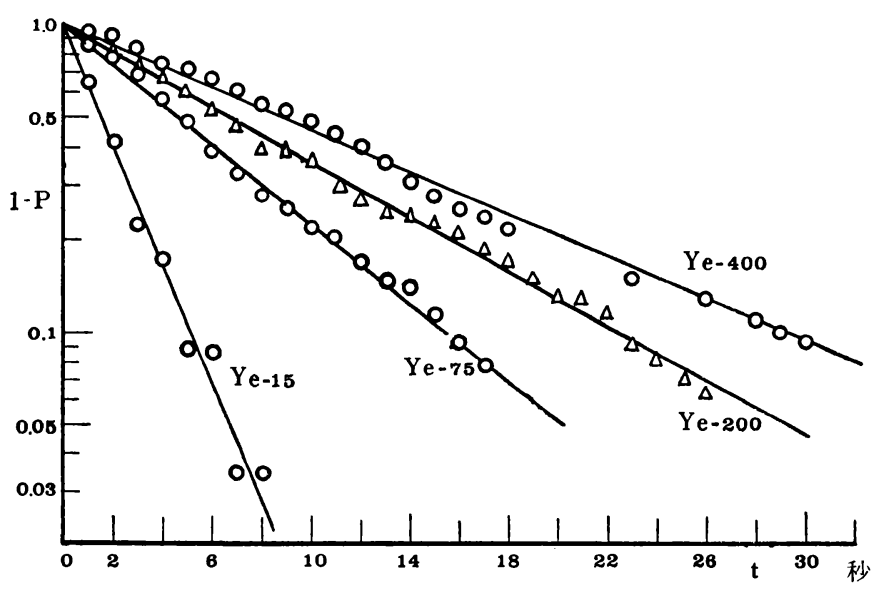

図 6 目標色カードの枚数 $n$ をパラメータと して $\log _{10}(1-P)$ 対 $\mathrm{t}$

Fig. $6 \log _{10}(1-P)$ to $t$ with a parameters of the number of yellow cards. (Yellow is the objective color.)

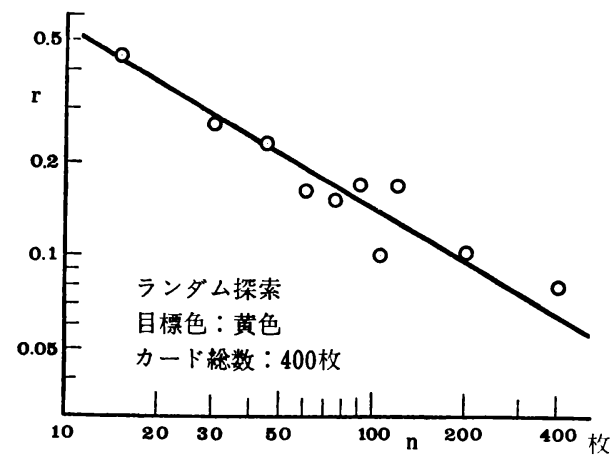

図 7 目標カード数 $n$ 対 $r$

Fig. $7 r$ wih respect to the number of cards of objective color $(n)$.

目標色を黄色から他の色に変え, 同様の実験の上 $\gamma$ を 抽出して, これを目標色の明度 $(Y)$ によって整理した ものを図 8 に示す. 目標色が明るいほど発見されやす い. この関係を実験式で示すと, $20<Y<100$ の範囲て

$$
r=0.05 Y^{0.25}
$$

をうる.この式は(2)式と類似しており，これから視標の 発見されやすさ $(r)$ は視標の明度の 0.25 乗に比例する といえる.たたし比例の定数は, 実験の種類や視標の形 状，性質によって相違する.

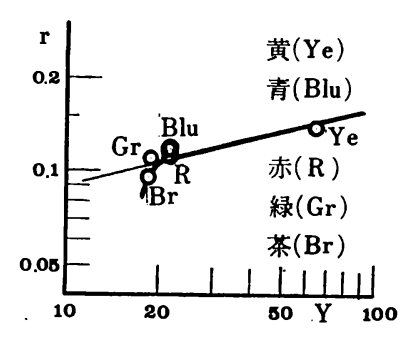

図 8 目標色の明度 $(Y)$ に対する $r$

Fig. $8 r$ with respect to the color lightness of each object.

さてもとにもどって，目標色が黄色の場合について発 見時間 $t$ の期待值を, $P$ およびR探索別にそれぞれ $E_{P}$, $E_{R}$ と表し，これらを目標色カードの枚数 $n$ によって整 理すると図 9 をうる. $n$ の増加とともに $E_{P}, E_{R}$ もとも に増加するが，勾配は $E_{R}$ の方が大きい. そこで $E_{P}$ と $E_{R}$ の比をとって $n$ についてプロットすれば図 10 のご とくになる. $E_{P} / E_{R}$ が 1 に等しくなる点が両探索法の 優劣の分岐点て， $n \cong 130$ 枚前後でる. すなわち全力 一ド数 400 枚中, 目標色カードがこの枚数以下ならばR 


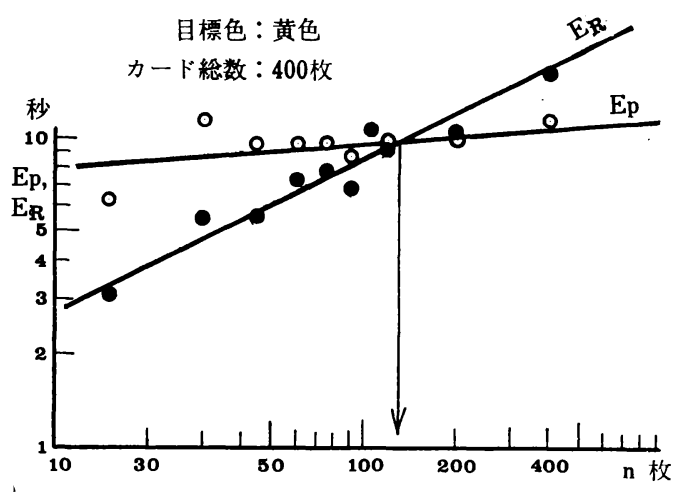

図 9 目標色カード枚数 $n$ に対する平均発見時間

$$
E_{P}, E_{R}
$$

Fig. 9 Mean time of finding $\left(E_{P}, E_{R}\right)$ with respect to $n$.

探索の方が有利であり，これ以上の枚数のときはP探索 が有利となる.

つぎに上記の実験を，配列カードの全てを目標色（こ の実験では黄色）一色とし（したがって環境色カードは なし)，その総枚数 $N$ を変えたときの目標カードの発見 確率を求めると図 11 に示すごとくになる．ｒのNに対 する勾配は図 7 の場合より大きく（3)式に対応して次式 をうる。

$$
r=59.09 N^{-1 \cdot 107}
$$

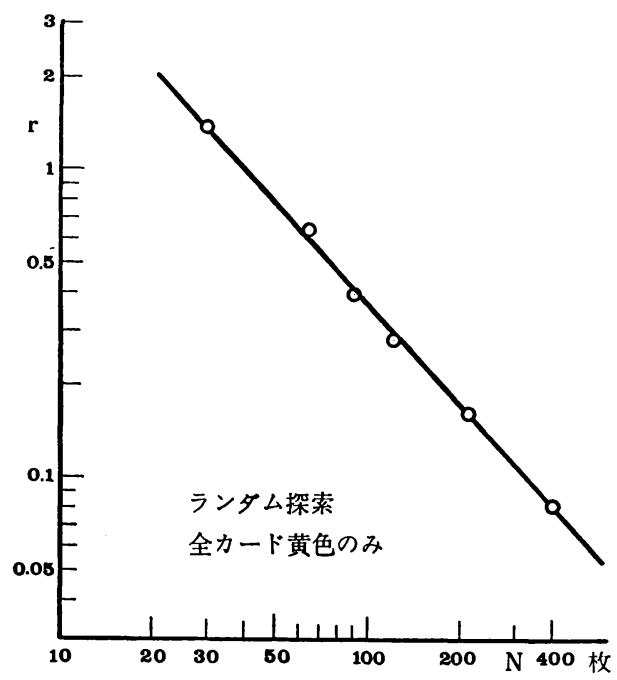

図 11 全カード黄色のとき $N$ 対 $r$

Fig. $11 \gamma$ with respect to the number of the total cards $(N)$, when all cards have the same objective color.

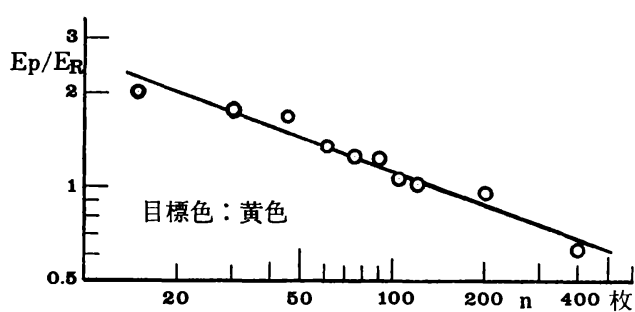

図 $10 n$ に対する $E_{P} / E_{R}$

Fig. $10 E_{P} / E_{R}$ with respect to $n$.

また $E_{P}$ と $E_{R}$ の值を図 9 と同様に $N$ についてプロ ットすれば図 12 となり，またさらに $E_{P} / E_{R}$ を $N に つ ~$ いて整理すれば図 13 をうる。困 10 と図 13 とは似てい るが，図10の方が勾配が急で，両図からそれぞれ

$$
E_{P} / E_{R}=6.09 n^{-0.368}
$$

および

$$
E_{P} / E_{R}=2.95 N^{-0.235}
$$

をうる。

\section{4. 考察}

色コードを併用した視標提示の方が，それを含まない 提示よりはるかに発見率が高いことは $\mathrm{Smith}^{10)}$ らの研 究にも指適されるとおりであるが, このような color coding との併用の場合でも, さらに特定色の視標群を 1 個所に集中した場合と，これらを分散した場合とで発 見時間に差が生じる.これは前述のカード実験におい て，たとえ目標值が誘目性の強い黄色であっても，これ らを環境色カード群中に散在させたときは, 探索経路中 に存在する環境色カードが探索の移動速度に対して明ら

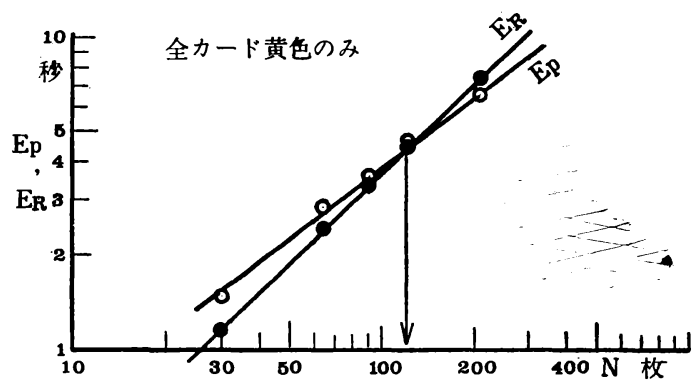

図 12 全カード数 $N$ に対する平均発見時間 $E_{P}, E_{R}$

Fig. 12 Mean time of finding $\left(E_{P}, E_{R}\right)$ with respect to $N$. 


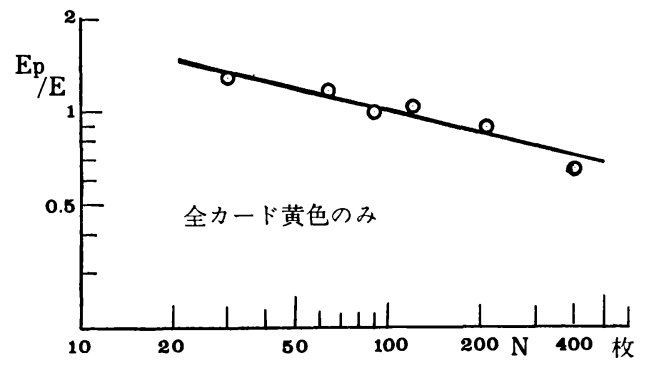

图 $13 N$ に対する $E_{P} / E_{R}$

Fig. $13 E_{P} / E_{R}$ with respect to $N$.

かな抵抗作用を用じさせる.すなわち眼は高い意識水準 の下で目標色カードのみを選択し, 他の色の空間は飛躍 すると考えがちであるが，実際はそうではなく無意識に 環境色カード群をも, それらの内容を認識しようとし, 情報（この際は直接には役に立たない情報）を抽出しよ うと試みてしまうものである.このことを実験值で示せ は, 目標色カード群中での視線の探索移動速度 $(v)$ は 平均して 13.65 枚/秒であるのに対し, 環境色カード群 中での移動速度は, 17.70 枚/秒程度で大きな差は認めら れない.すなわち視線は環境色カードを無視して飛ぶこ とはできないのである.したがって目標カードが広く分 散しているときは，探索パスがそれだけ長くなるから探 索に要する時間も長くなる. 逆に目標色カードを 1 個所 に集め視線の移動距離を短くすれば，探索時間は当然短 くなる.

以上のことを具体的に示したのが図 9 および図 12 で あり, 図 9 は目標色カード群が散在するときの平均発見 時間に, 図 12 は目標色カード群を 1 個所に集中したと きの発見時間に相当している.

この際カードを探すのに前述のごとく，P探索と $R$ 探 索とがあるが, 目標色の枚数 $n$ が少ないときは $R$ 探索に よって一目で見分けた方が早い.しかし $几$ が增せば $P$ 探 索て順序上く探す方が早く発見でる. 図 9 でかりに $E_{P}$ と $E_{R}$ が等しいときの值を見ると約 9.5 秒である.

これに対し図 12 では， $P$ とRの探索時間の差は図 9 の それほどではない. 四から $E_{P}=E_{R}$ のところの值は約 4.5 秒と読めるから，目標色カードを 1 個所に集めた方 が発見の点から約 2 倍有利となる. 目標色カードの枚数 が少ないときは，図 9,12 ともR探索の方が有利である ので両図の $E_{R}$ の值を比較すると, たとえば $n=N=$ 30 のとき,カード分散時では 4.7 秒, カード集中時では 1.15 秒となって, 目標色カードを集中させるやり方の有 利さがいっそう明瞭である.
さて, 視覚表示に関連する問題は自動販売機の読取り 操作や図表や地図上での探索等, 日常多く経験するとこ ろである. そしてこれらの多くは，単純な知覚による発 見の問題だけではなく連想や類推を伴う場合が多いここ の連想と発見の関係は興味深い問題の 1 つであるが, し かしいかなる発見の形態にせよ, まずとにかく対象の知 覚が必要であり, その遅速が発見の速さの基礎となる. そしてこの発見の難易さを测る指標として, 筆者は瞬間 発見確率密度を導入した. 一般には $r$ は時間の $t$ 関数と して,

$$
P(t)=1-e^{-\int_{0}^{t} r d t}
$$

の形で表される ${ }^{14)} . r か ゙ t$ には無関係に一定ならぱ, (8) は(1)式に一致する．そして本報告のいずれの実験です(1) 式が大体満足されることを示している.

いま時刻 $t$ までは発見できなくて, 続く短い時間区間 $(t, t+\Delta t)$ ではじめて発見が生じる確率は $(1-P) r \Delta t$ で 与えられるから, 発見に要する時間の期待值を $E$ と書く と，(1)式を用いて

$$
E=\int_{0}^{\infty} t\left(1-P(t) \gamma d t=\int_{0}^{\infty} t e^{-\gamma t} \gamma d t=1 / \gamma\right.
$$

こ書けるから，(1)式が成立するならば，rの逆数は発見 時間の平均値に等しい。

\section{5. むすび}

1. 視標 (目標物) が背景から明瞭に区別されるほど rの值は大きくなるが，この関係を色の明度を使って定 量的に把握することを試み，(2)，(4)の実験式をえた．そ してこの両式は, 明度に関して同一の指数をもち, 種類 の違う 2 つの実験に共通する関係を示している.

2. カードによる発見探索において, 目標と同じ色彩 のカード数が増えるほど発見は困難となるが，その関係 は(3)式によって与えられる.

3. 目標色カードを一群に集め, 環境色カードを引き 離したときの方が, 両者が混在するときよりはるかに大 きいとをもつ．たとえば，目標カード数を 30 枚とした ときの両者の比は, 図 7,11 または(3)，(5) 式により。 $r_{n} / \gamma_{N}=0.28 / 1.35=1 / 4.82$ であるから, (9)式の関係から $E_{n} / E_{N}=4.82$ となる. すなわち目標色カードが散在し ているときは，集中しているときに比へて約 5 倍発見時 間がかかることを示している. しかしこの違いは目標色 カードの枚数の増加につれて減少し, たとえば 200 枚の ときをみると, $E_{n} / E_{N}=1.8$ である. これは 400 枚のカ 一ド中 200 枚が目標色カードで占められている場合であ るから, 散在と集中の意味の差が少なくなることから当 
然納得できる.

4. われわれは, 日常ものを探すとき, 何らかの意味 て $P$ 探索か $R$ 探索かの選択を迫られる. 本報での実験に より両者の此が，(6)および(7)式て与えられることが判明 した.

以上の結果はすべて本実験に用いた視標やカードの寸 法（視角）に基づいている. 視角が異なれば上記の結果 も変わるかも知れず, 視角との関係を調べる必要があ る. さらに混合探索についても研究し, 場合に応じた最 適な探索法の開発が期待される.

\section{参考文献}

1) McCormick, E.J.;Human Factors Engineering, McGraw-Hill, 1970

2) 大島正光: 人間工学, コロナ社, 昭和 47 年

3 ）倉田正一; 人間工学, 技報堂, 昭和 49 年

4 ) 長沢有恒; 航空機の計器表示と配列, 人間工学, Vol. 4, No. 1

5 ）渡辺 慧; 認識とパタン, 岩波新書, 昭和 53 年

6 ) Lipkin, B.S., et al. ; Picture Processing and
Psychopictorics, Academic Press, 1970

7 ）福田信毅, 他; 円形計器の視認性についての研究, 人間工学, Vol. 13, No 2

8 ) Hitt, W.D. ; An Evaluation of five different Abstract Coding Methods, Human Factors, July, 1961, vol. 3, No. 2

9) Smith. S.L., and Thomas, D.W. ; Color versus Shape Coding in Information Displays, Journal of Applied Psychology, vol. 481964

10) Smith, S. L. ; Display Color Coding for visual Separability, MITRE Report MTS-10, Ang, 1963

11）谷島一嘉, 他 ; 二輸自動車の被視認性の定量化, 日本人間工学会第 19 回大会論文集

12）石橋富和, 他; 位置認知の手がかりとしての色彩 情報, 日本人間工学会第 19 回大会論文集

13）伊藤郁男；一点を凝視したときのランダムな視標 の発見確率について, 人間工学, Vol.14, No. 3

14）多田和夫，探索理論，日科技連，1973 